\title{
Karakteristik Lahan terhadap Kerentanan Pesisir Pantai Kabupaten Rembang, Jawa Tengah
}

\author{
Abiyani Choirul Huda*, Ibnu Pratikto, Rudhi Pribadi \\ Departemen IImu Kelautan, Fakultas Perikanan dan IImu Kelautan, Universitas Diponegoro \\ Jl. Prof.H.Soedarto S.H, Tembalang,Semarang, Jawa Tengah 50275 Indonesia \\ *Corresponding author, e-mail : abyxavi354@gmail.com
}

\begin{abstract}
ABSTRAK : Kerentanan pantai adalah kondisi yang menggambarkan keadaan mudah terkena dari suatu sistem alami serta keadaan sosial pantai. Kerentanan pantai yang diakibatkan erosi merupakan ancaman yang dapat menimbulkan kerugian yang besar bila tidak ditangani dengan tepat. Perlu dilakukan sebuah upaya mitigasi bencana erosi pantai berupa tahap awal dengan penilaian indeks kerentanan pantai. Upaya mitigasi bencana dapat dimulai dengan membuat pemetaan indeks kerentanan pantai yang berdasarkan penilaian lima variabel, yaitu: geomorfologi pantai, tipologi pantai, kemiringan pantai, vegetasi mangrove, dan penggunaan lahan pesisir. Metode yang digunakan dalam penelitian ini adalah metode spasial yang digunakan untuk menyusun peta tingkat kerentanan pantai yang diawali dengan input data ataupun peta berdasarkan pada variable yang ditentukan, dilanjutkan dengan metode kuantitatif yang digunakan untuk menganalisa data yang tersaji dalam bentuk angka dengan menggunakan sistem skoring, dilanjutkan dengan metode deskriptif yang digunakan dalam mendeskripsikan sejumlah variabel yang berkenaan dengan penelitian. Penelitian ini dilakukan pada bula Mei-Agustus 2017, lokasi penelitian berada di kawasan pesisir pantai Kabupaten Rembang pada 6 Kecamatan Pesisir dan 40 desa. Hasil dari penelitian ini berdasarkan penilaian Indeks Kerentanan Pantai di Kabupaten Rembang didapatkan tingkat kerentanan sangat tinggi (400-450) berada di Kecamatan Kaliori, kerentanan tinggi (360-400) berada di Kecamatan Sarang, Kragan, dan Lasem, kerentanan sedang (290-360) berada di Kecamatan Sluke, dan kerentanan rendah (240-290) berada di Kecamatan Rembang. Dari lima variabel, yang sangat berpengaruh terhadap kerentanan bencana erosi pantai adalah tipologi pantai.
\end{abstract}

Kata kunci : Abrasi, Erosi, Kerentanan pantai

\section{Land Characteristics of Rembang Coastal Coastal Vulnerability, Central Java}

ABSTRACT : Coastal vulnerability is a condition which describes the State of a system of easily affected by natural and social circumstances of the beach.Coastal vulnerability arising from erosion is a threat that can cause great harm if not handled appropriately. Need a coastal erosion hazard mitigation efforts in the form of an early stage with an assessment of the vulnerability index beach.Disaster mitigation efforts can be initiated by creating a mapping coastal vulnerability index based on the assessment of the five variables, namely: coastal geomorphology, typology, the slope of the Beach Coast, mangrove vegetation, and land use. The methods used in this research are spatial methods used to draw up a map of the level of vulnerability of beach, begins with the input data or map based on variable is specified, followed by a quantitative method used to analyze the data that is presented in the form of numbers by using the scoring system, followed by a descriptive method used in describing a number of variables related to the research. This research was conducted in May-August 2017, the location of the research lies in the coast of Rembang in 6 sub-districts and 40 villager. The results of this research are based on the assessment of the vulnerability index Beach in Rembang in the level of very high vulnerability (400-450) is located in district kaliori, high vulnerability (360-400) is located in the subdistrict of Sarang, Kragan and Lasem, medium vulnerability (290-360) is located in district of Sluke, and low vulnerability (240-290) located in the subdistrict of Rembang. From the fifth of these variables, a very influential towards the erosion of coastal disaster vulnerability is the beach typology.

Keywords : Abrasion, Erosion, Coastal vulnerability 


\section{PENDAHULUAN}

Pantai adalah perbatasan antara dataran dan lautan yang dipengaruhi oleh pasang tertinggi dan air surut terendah (Setyandito, 2012). Dimana daerah dataran adalah daerah yang terletak diatas permukaan dataran dimulai dari garis pasang tertinggi, sedangkan daerah lautan adalah daerah yang terletak dibawah permukaan laut dimulai dari sisi laut pada garis surut terendah (Triadmojo, 1999). Pemanfaatan pantai sebagian besar adalah sebagai kawasan permukiman, dimana lebih dari $70 \%$ kota besar di dunia berada di daerah pantai. Hal ini terkait erat dengan potensi yang dimiliki pantai berupa daya tarik visual. Potensi lain pesisir adalah sebagai daerah permukiman, budidaya perikanan, tambak, pertanian, pelabuhan, pariwisata, dan sebagainya.

Mangrove memiliki peranan penting dalam melindungi pantai dari gelombang, angin dan badai. Selain itu, kemampuan mangrove dalam menangkap sedimen berfungsi untuk mengembangkan wilayahnya ke arah laut. Fungsi ekologis hutan mangrove antara lain: pelindung garis pantai, mencegah intrusi air laut, habitat, tempat mencari makan (feeding ground), tempat asuhan dan pembesaran (nursery ground), tempat pemijahan (spawning ground) bagi aneka biota perairan, serta sebagai pengatur iklim mikro.

Indonesia sebagai negara kepulauan terbesar di dunia yang memiliki sekitar 17.508 pulau dengan panjang garis pantai $81.000 \mathrm{Km}$, memiliki potensi sumber daya pesisir dan lautan yang sangat besar (Bengen, 2001). Besarnya potensi sumber daya kelautan Indonesia, seperti potensi sumber daya ikan laut di seluruh perairan Indonesia (tidak termasuk ikan hias) diduga sebesar 6,62 juta ton per tahun tercermin pada besarnya keanekaragaman hayati (Budiharsono S, 2001). Disisi lain, jumlah penduduk yang meningkat cepat beserta intensitas pembangunan sumber daya alam di dataran sudah mulai menipis dan dengan kenyataan bahwa $60 \%$ dari penduduk Indonesia (kira-kira 185 juta jiwa) yang dianggap tinggal di pesisir, tidaklah mengherankan bahwa lingkungan pesisir menjadi pusat pemanfaatan sekaligus pengrusakan yang tingkatnya sudah cukup parah untuk beberapa daerah tertentu. Salah satu bentuk pemanfaatan pesisir yang merusak adalah peralihan penggunaan lahan vegetasi mangrove menjadi lahan permukiman dan sebagai area tambak. Penurunan kualitas dan kuantitas vegetasi mangrove dapat mempengaruhi keseimbangan ekosistem pesisir. Kerusakan keseimbangan ekosistem dan habitat pesisir dapat meningkatkan laju erosi dan abrasi pantai. Erosi pantai didefinisikan sebagai mundurnya garis pantai dari posisi asalnya (Triatmodjo, 1999), sedangkan abrasi pantai adalah suatu proses pengikisan pantai (Setiyono, 1996).

Erosi dan abrasi pantai pada dua dekade terakhir ini telah menyebabkan kerusakan pantai di berbagai wilayah pantai di Indonesia yang mengancam kehidupan dan penghidupan masyarakat pesisir (Wahyudi, 2009). Kerusakan pantai di kawasan pesisir berdampak terhadap terganggunya aktivitas sehari-hari masyarakat, terganggunya sistem transportasi, industri, dan perdagangan, serta dampak lingkungan dan kesehatan masyarakat. Tingkat kerusakan pantai dapat diketahui dengan metode penilaian Indeks Kerentanan Pantai.

Indeks kerentanan pantai merupakan metode yang menggunakan beberapa variabel sebagai penilaiannya. Metode ini paling umum digunakan di seluruh dunia dalam kajian kerentanan pantai (Gornitz, et al., 1997). Kondisi kerentanan pantai dapat dinilai dari dua faktor seperti gejala fisik pantai dan gejala oseanografi pantai. Gejala fisik merupakan bentuk gejala yang dialami pada permukaan bumi, seperti geomorfologi pantai, tipologi pantai, dan sebagainya, sedangkan gejala oseanografi pantai merupakan bentuk gejala yang terjadi diperairan pantai seperti pasang surut, arus, gelombang, dan sebagainya.

\section{MATERI DAN METODE}

Penelitian di kecamatan pesisir Kabupaten Rembang ini merupakan penelitian untuk menghitung tingkat kerentanan pantai. Aspek yang diambil pada penilitian ini adalah tipologi pantai, vegetasi mangrove, geomorfologi pantai, kemiringan pantai, dan penggunaan lahan pesisir. Data tersebut digunakan sebagai perhitungan tingkat kerentanan pantai. Materi yang digunakan dalam penelitian kerentanan pantai Kabupaten Rembang meliputi lima variabel, yaitu tipologi pantai, vegetasi mangrove, geomorfologi pantai, kemiringan pantai, dan penggunaan lahan pesisir. Materi yang digunakan dalam penelitian Indeks Kerentanan Pantai (IKP) adalah perhitungan 
kerentanan pesisir Kabupaten Rembang terhadap ancaman kerusakan. Data yang dibutuhkan sebagai membantu penelitian ini berupa data primer dan skunder.

Metode yang digunakan dalam penelitian ini adalah metode survei lapangan, analisis data, dan metode perhitungan Indeks Kerentanan Pantai. Data yang diperoleh diklasifikasikan berdasarkan tingkat kerentanan pesisir menurut Gornitz (1991). Hasil dari klasifikasi tersebut selanjutnya dihitung nilai kerentanan dengan menggunakan persamaan Indeks Kerentanan Pantai. Pengolahan data dilakukan menggunakan beberapa perangkat lunak.. Penentuan lokasi penelitian dapat dilihat pada Gambar 1.

\section{Metode Pengambilan Data}

Sumber data tipologi pesisir pantai Kabupaten Rembang diperoleh dangan mengidentifikasi citra QuickBird berdasarkan kriteria tipologi pantai yang tertera pada Tabel 10. Tahapan yang dilakukan dalam mengidentifikasi variabel tipologi pantai : Citra - Crooping - Identifikasi Klasifikasi-Data Tipologi Pantai

Predicition Tool :Proses mendapatkan data mangrove ini dilakukan dengan sistem penginderaan jauh dan survei lapangan. Proses dilakukan dengan bantuan citra satelit Landsat 8 tahun 2017 dengan melakukan komposit warna. Komposit warna dilakukan untuk mempermudah dalam interprestasi secara visual, yaitu dengan menonjolkan masing-masing saluran yang ada dalam citra satelit Landsat 8. Komposit warna yang digunakan yaitu kombinasi saluran 543 . Tahapan yang dilakukan dalam mengidentifikasi variabel vegetasi mangrove pantai : Citra Komposit Warna 534 - Identifikasi - Klasifikasi- Data Vegetasi Mangrove

Survei Lapangan : Pengamatan vegetasi mangrove dilakukan dengan metode line transek yaitu dengan melakukan plotting area pada suatu area tertentu pada habitat ekosistem mangrove. Line transek ini berupa plotting area berukuran $10 \times 10 \mathrm{~m}$ atau $5 \times 20 \mathrm{~m}, 5 \times 5 \mathrm{~m}$ dan $1 \times 1 \mathrm{~m}$. Pada plot area berukuran $10 \times 10 \mathrm{~m}$ atau $5 \times 20 \mathrm{~m}$ (menyesuaikan dengan kondisi mangrove yang ada di lokasi sampling), dilakukan pengambilan data pohon (dbh $\geq 4 \mathrm{~cm})$. Sedangkan pada plot area berukuran $5 \times 5 \mathrm{~m}$ dilakukan pengambilan data sapling $(1 \mathrm{~cm} \leq \mathrm{dbh}<4 \mathrm{~cm})$ dan pada plot area berukuran $1 \times 1 \mathrm{~m}$ dilakukan pengambilan data seedling (anakan) dengan ketinggian $<1 \mathrm{~m}$.

Geomorfologi Pantai : Sumber data geomorfologi pesisir pantai Kabupaten Rembang diperoleh dengan mengidentifikasi citra Landsat 8 berdasarkan kriteria geomorfologi berdasarkan seperti tertera pada Tabel 10. Tahapan yang dilakukan dalam mengidentifikasi variabel geomorfologi : Citra - Crooping - Identifikasi - Klasifikasi- Data Geomorfologi Pantai

Kemiringan Pantai : Data elevasi diperoleh dengan cara mengunduh dari situs EarthExplorer-USGS (https://earthexplorer.usgs.gov). Data yang diunduh dari situs tersebut berupa Digital Elevation Model (DEM). Resulusi spasial yang dimiliki oleh data ini sebesar 1 arc
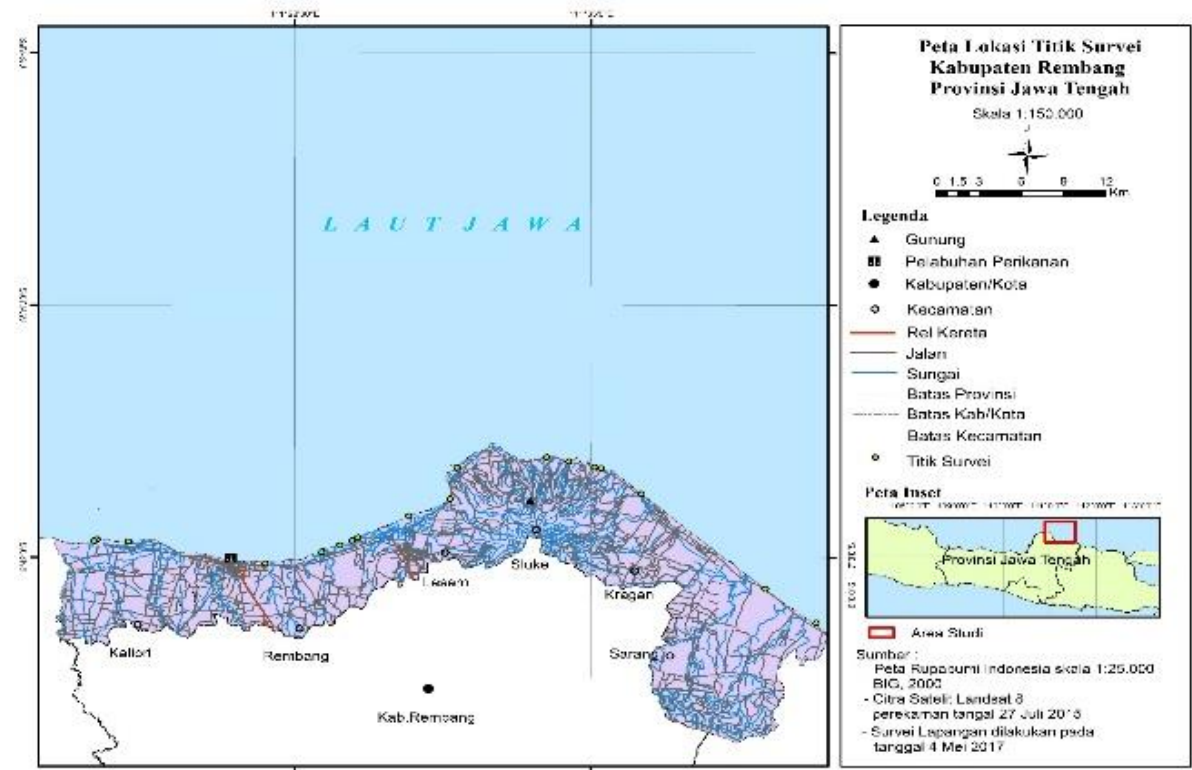

Gambar 1. Lokasi Penelitian Kajian Kerentanan Pantai di Kabupaten Rembang 


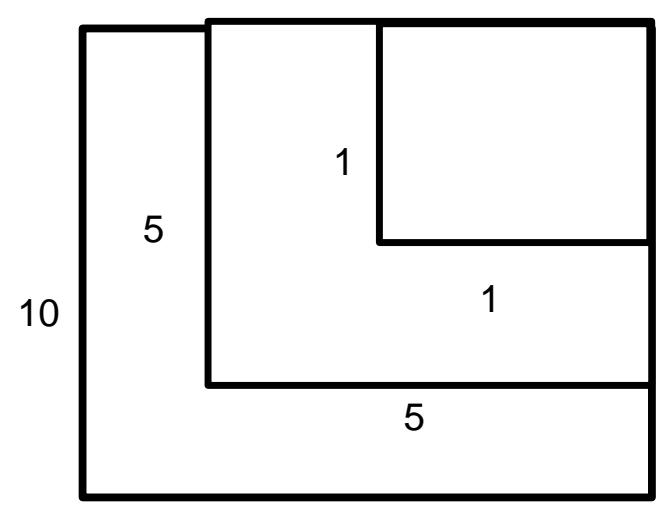

10

Gambar 2. Cara peletakan plot dan sub plot pengambilan data. a: $10 \mathrm{~m} \times 10 \mathrm{~m}$ untuk kategori pohon, b: $5 \mathrm{~m} \times 5 \mathrm{~m}$ untuk kategori anakan (sapling), c: $1 \mathrm{~m} \times 1 \mathrm{~m}$ untuk kategori semai (seedling) (Pribadi, 2016).

second atau 30×30 m. pengolahan data elevasi dilakukan dengan menggunakan perangkat lunak ArcGis : Data DEM ASTER - Koreksi dengan Digitasi- Koreksi Kontur ke Point - Koreksi Point ke Raster - Klasifikasi - Koreksi Raster ke Vektor - Ranking - Data Elevasi

Penggunaan Lahan Pesisir : Metode klasifikasi penggunan lahan, yaitu dengan maximum likelihood classification (MLC) dipilih untuk klasifikasi tutupan lahan citra landsat 8. MCL merupakan metode yang paling umum digunakan dalam klasifikasi data remote sensing (Foody et al., 1992). MCL mempertimbangkan faktor peluang dari satu piksel untuk dikelaskan ke dalam kelas atau kategori tertentu. Peluang ini sering disebut prior probability, dapat dihitung dengan menghitung persentase tutupan pada citra yang akan diklasifikasi. Dengan melalui proses supervised maka citra yang didapat dilakukan pendigitan. Pendigitan dilakukan sesuai dengan klasifikasi yang telah ditentukan. Dalam mengeksekusi klasifikasi ini digunakan algoritma. Algoritma yang digunakan dalam kajian ini adalah algoritma kemiripan maksimum (Maximum Likelihood Algorithm) (Danoedoro, 1996).

\section{Analisis Data}

Data kerentanan pantai menggunakan tolak ukur parameter tipologi pantai, vegetasi mangrove, geomorfologi pantai, kemiringan pantai, dan penggunaan pantai, sebagai berikut : Konsep dari analisis ini menggunakan citra QuickBird yang di crooping atau pemotongan merupakan tahapan pertama yang dilakukan. Citra QuickBird dipotong berdasarkan Kecamatan yang terdapat pada daerah pesisir. Citra yang telah dipotong kemudian diidentifikasi berdasarkan klasifikasi tutupan lahan. Hasil identifikasi yang telah diperoleh selanjutnya diklasifikasikan berdasarkan klasifikasi variabel tipologi pantai oleh Suprapto (2011). Klasifikasi dibagi menjadi 5 kelas kerentanan, yaitu kelas sangat rendah dengan score 1 berupa pantai berkarang, kelas rendah dengan score 2 berupa pantai berbatu, kelas sedang dengan score 3 berupa pantai berpasir, kelas tinggi dengan score 4 berupa pantai berpasir, dan kelas sangat tinggi dengan score 5 berupa pantai berlumpur.

Analisa kerapatan mangrove dari citra satelit ini dilakukan berdasarkan hasil perhitungan indeks vegetasi, yaitu menggunakan transformasi NDVI (Normalized Difference Vegetation Index) dengan menggunakan saluran 4 (inframerah) dan saluran 3 (merah). Klasifikasi variabel vegetasi mangrove dibagi menjadi dua kelas kerentanan yaitu rentan dan tidak rentan, kelas rentan diambil berdasarkan nilai penutupan lahan yang rendah sedangkan kelas tidak rentan dengan niali penutupan yang lebat. Indeks vegetasi merupakan suatu algoritma yang diterapkan terhadap citra untuk menonjolkan aspek kerapatan (Gambar 3).

$$
N D V I=\frac{\text { saluran infra merah dekat }- \text { saluran merah }}{\text { saluran infra merah dekat }+ \text { saluran merah }}
$$




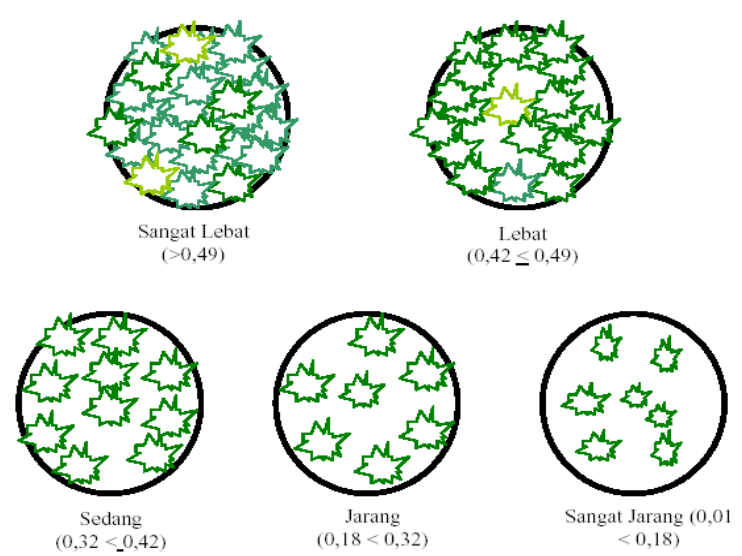

Gambar 3. Ilustrasi tingkat kerapatan kanopi dan kisaran kelas kerapatan nilai NDVI (Dewanti, 1996)

Konsep dari analisis ini menggunakan citra landsat 8 yang di crooping atau pemotongan merupakan tahapan pertama yang dilakukan. Citra QuickBird dipotong berdasarkan Kecamatan yang terdapat pada daerah pesisir. Citra yang telah dipotong kemudian diidentifikasi berdasarkan klasifikasi tutupan lahan. Hasil identifikasi yang telah diperoleh selanjutnya diklasifikasikan berdasarkan klasifikasi variabel geomorfologi pantai oleh Suprapto (2011). Klasifikasi geomorfologi pantai dibagi menjadi 5 kelas keretanan, yaitu kelas sangat rendah dengan score 1 berupa pegunungan denudasional, kelas rendah dengan score 2 berupa rataan pasang surut, kelas sedang dengan score 3 berupa aluvial, kelas tinggi dengan score 4 berupa estuari, dan kelas sangat tinggi dengan score 5 berupa delta.

Data kemiringan pantai diklasifikasikan kemudian dikonversi menjadi bentuk format vector dengan grid sebesar $30 \times 30 \mathrm{~m}$. ukuran grid dengan $30 \times 30 \mathrm{~m}$ dipilih dengan pertimbangan resulusi spasial data ASTER. Hasil data tersebut lalu di klasifikasi menjadi 2 kelas kerentanan, yaitu kelas tinggi berupa pantai curam dengan score 5 dan rendah berupa pantai landai dengan score 1.

Informasi penggunaan lahan dalam kajian ini terbagai menjadi tujuh bentuk, yaitu tambak, tanah terbuka, lahan pertanian, semak belukar, permukiman, kebun campuran, dan hutan/huta rawa. Data tersebut di klasifikasikan berdasarkan nilai, yaitu permukiman dangan score 7 , tambak dengan score 6 , tanah terbuka dengan score 5 , lahan pertanian dengan score 4 , semak belukar dengan score 3, kebun campuran dengan score 2, dan hutan/hutan rawa dengan score 1.

Analisa berdasarkan variabel tersebut bertujuan untuk menyusun tingkat kerentanan pantai. perhitungan yang dikenal dengan Coastal Vulnerability Index (CVI) atau Indeks Kerentanan Pantai (IKP) dilakukan dengan memasukkan setiap nilai variabel yang ada kedalam persamaan kerentanan fisik dengan persamaan sebagai berikut: $I K P=(30 x T I)+(25 x M i)+(20 x G i)+$ $(15 x \mathrm{Ki})+(10 x \mathrm{Pli})$. Keterangan: $\mathrm{Ti}$ : Indeks Tipologi Pantai; Mi : Indeks Vegetasi Mangrove; Gi : Indeks Geomorfolaogi Pantai; Ki : Indeks Kemiringan Pantai; Pli : Indeks Penggunaan Lahan Pesisir; IKP : Indeks Kerentanan Pantai

\section{HASIL DAN PEMBAHASAN}

Kondisi geologi berdasarkan peta geologi pesisir Kabupaten Rembang, Kecamatan Kaliori dengan kondisi aluvial, yaitu berupa lanau dan lempung. Kecamatan Rembang dengan kondisi aluvial, yaitu berupa kerikil, kerakal, lanau, dan lempung. Kecamatan Lasem dengan kondisi aluvial, yaitu berupa kerikil, kerakal, dan lanau dan breksi Gunung Api Lasem, yaitu berupa lava, andesit, algomerat, dan breksi. Kecamatan Sluke dengan kondisi breksi Gunung Api Lasem. Kecamatan Kragan dan Kecamatan Sarang dengan kondisi aluvial, yaitu berupa kerikil, kerakal, dan pasir putih.

Kabupaten Rembang terdiri dari tiga bentuk tipologi pantai yaitu pantai berpasir, pantai berlumpur, dan pantai berbatu. Kecamatan dengan tipologi pantai berupa pantai berlumpur berada di dua Kecamatan yang saling berdekatan, yaitu Kecamatan Kaliori dan Kecamatan Rembang. 
Kecamatan Kaliori dijumpai keseluruhan berupa pantai berlumpur, yaitu dari Desa Tunggul Sari sampai Desa Pantiharjo, sedangkan pada Kecamatan Rembang terdapat tiga desa berupa pantai berlumpur, yaitu Desa Kabongan Lor, Tireman, dan Pasarbanggi, desa lainnya berupa berpasir (Gambar 4).

Pantai berpasir dijumpai keseluruhan desa pesisir pada Kecamatan Lasem, Kragan, dan Sarang. Kecamatan Sluke yang letaknya berupa dataran tinggi yang berupa pegunungan denudasional menjadikan disepanjang pantai berupa tipologi berbatu. Berikut peta tipologi pantai Kabupaten Rembang.

Hasil yang didapat menunjukkan bahwa Kecamatan Kaliori dan Kecamatan Rembang memiliki mangrove yang dapat dilihat melalui teknik pengindraan jauh menggunakan citra satelit landsat 8 perekaman tahun 2017. Berdasarkan hasil sebaran mangrove di Kabupaten Rembang berada di Kecamatan Kaliori dan Kecamatan Rembang (Gambar 6).

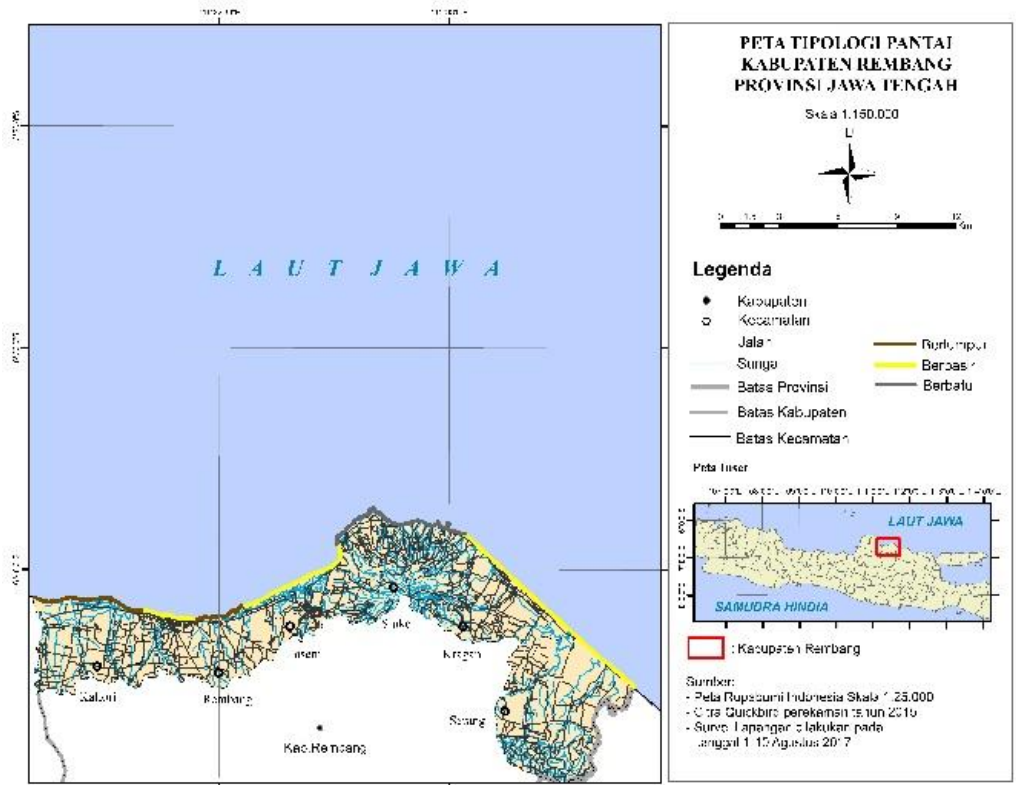

Gambar 4. Peta Tipologi Pantai Kabupaten Rembang
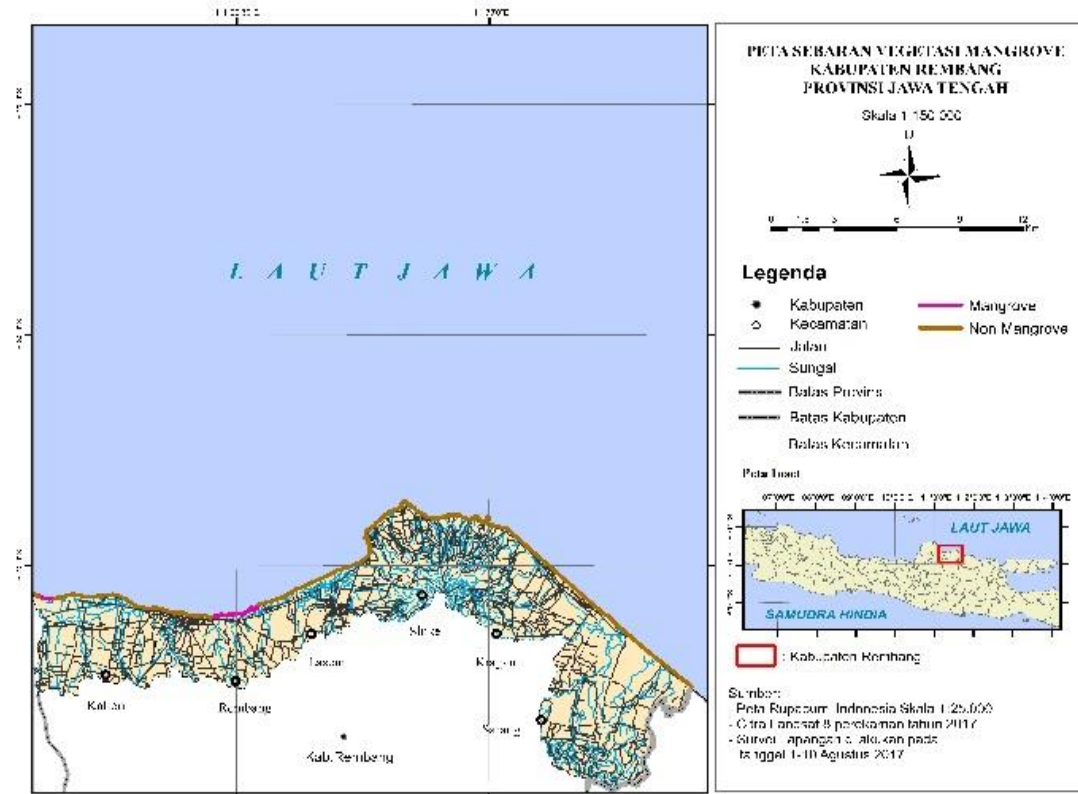

Gambar 5. Peta Sebaran Vegetasi Mangrove Kabupaten Rembang 
Pesisir Kabupaten dikelompokan enam Janis penutupan lahan, yaitu permukiman, tambak, tanah terbuka, lahan pertanian, kebun campuran, dan hutan/hutan rawa. Sebagian besar tutupan lahan Kabupaten Rembang berupa tambak dan permukiman. Permukiman dan tambak diidentifikasikan sebagai bentuk lahan dataran rendah. Oleh karena itu, dapat disimpulkan bentuk geomorfologi Kabupaten Rembang di dominasi oleh dataran aluvial yang menjadikan kawasan tersebut cukup rawan terhadap ancaman bencana abrasi dan erosi pantai. Daerah aluvial berada di seluruh kecamatan Kabupaten Rembang kecuali Kecamatan Sluke yang berupa pegunungan denudasional dan sebagian Kecamatan Rembang dan Kaliori berupa rataan pasang surut. Geomorfologi untuk rataan pasang surut diidentifikasikan berdasarkan tutupan lahan hutan/hutan rawa dalam kajian ini adalah tutupan vegetasi mangrove. Oleh karena itu, geomorfologi rataan pasang surut cukup aman terhadap ancaman bencana abrasi dan erosi pantai sebab adanya vegetasi mangrove sebagai pelindung pantai. Daerah rataan pasang surut berada di Kecamatan Kaliori dan Rembang (Gambar 7).

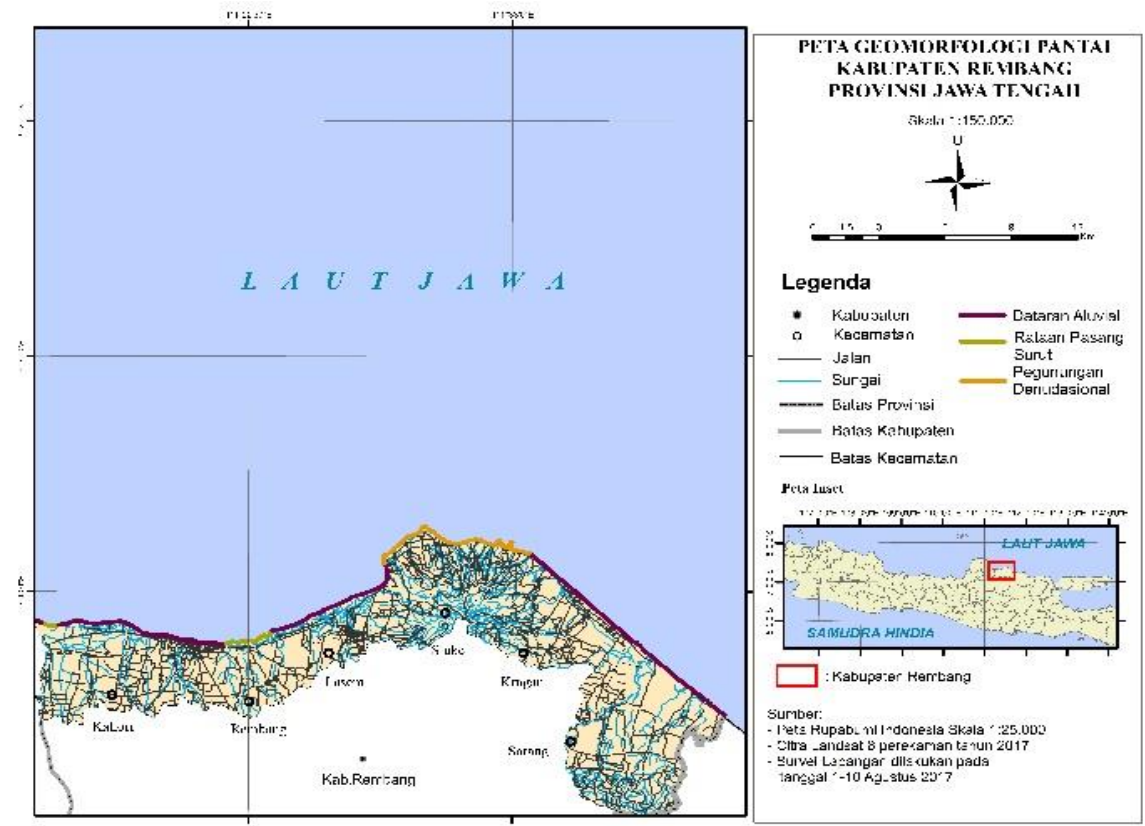

Gambar 7. Peta Geomorfologi Pantai Kabupaten Rembang
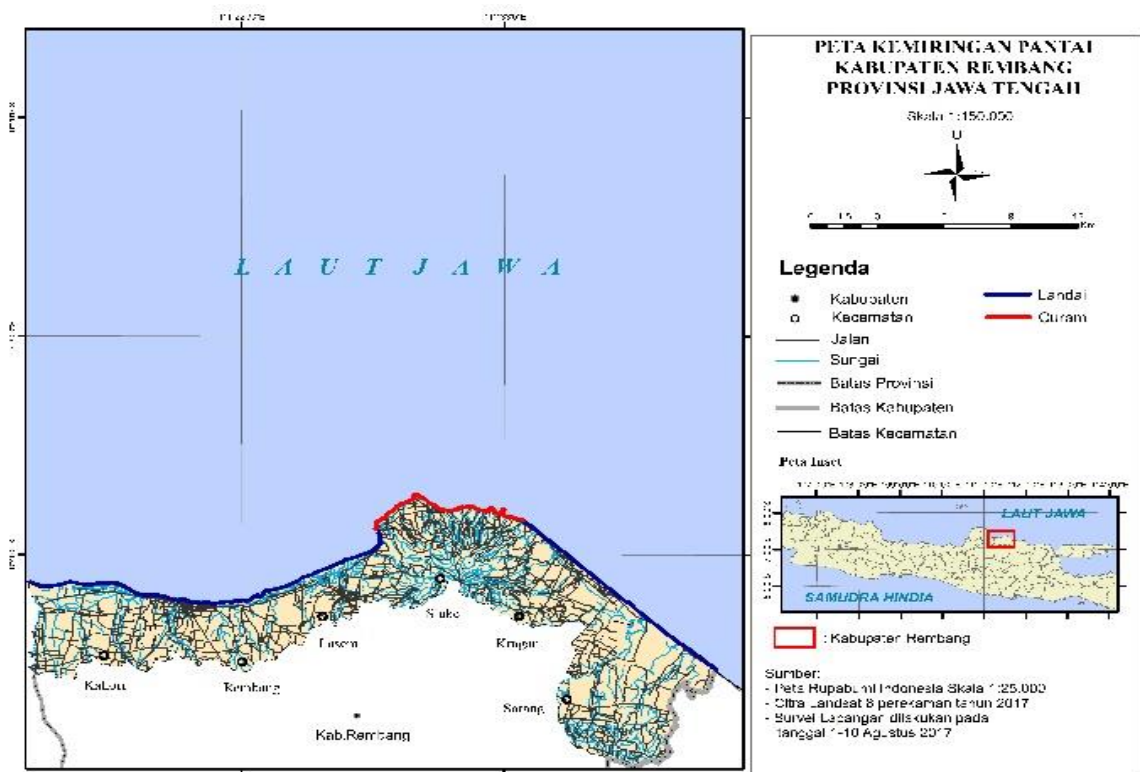

Gambar 8. Peta Kemiringan Pantai Kabupaten Rembang 


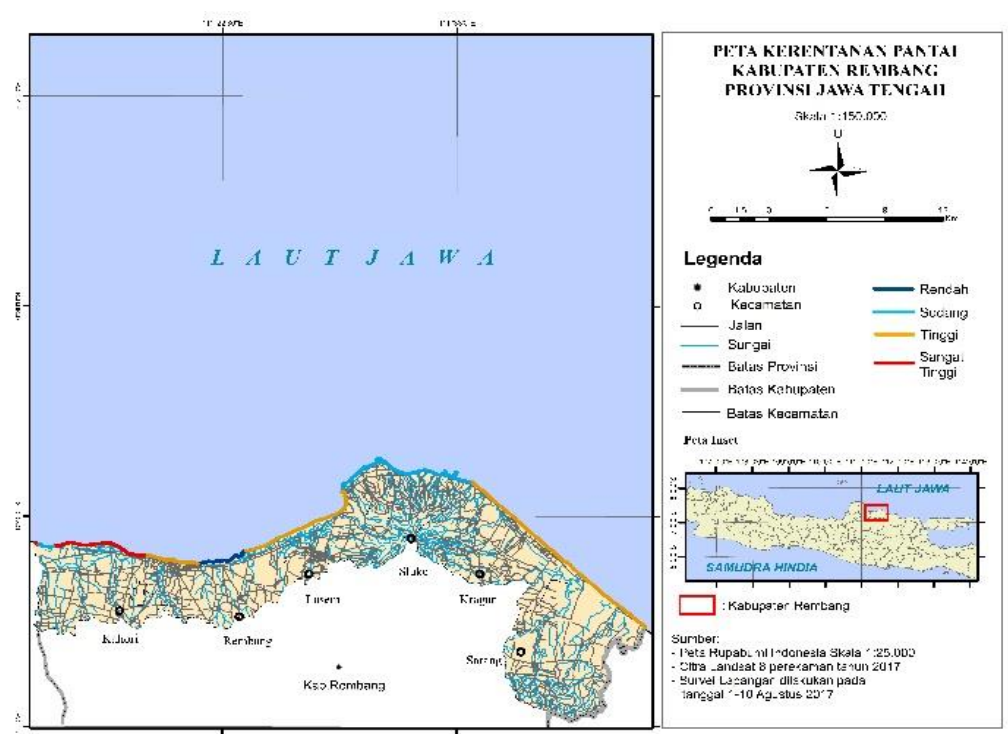

Gambar 9. Peta Kerentanan Pantai Kabupaten Rembang

Berdasarkan parameter kemiringan pantai wilayah pesisir pantai Kabupaten Rembang didominasi kelas kerentanan tingkat rendah, yaitu Kecamatan Kaliori, Kecamatan Rembang, Kecamatan Lasem, dan Kecamatan Sarang. Kecamatan Sluke dan Desa Binangun, Kecamatan Lasem memiliki tingkat kerentanan tingkat tinggi (Gambar 8).

Berdasarkan pada peta penggunaan lahan Kabupaten Rembang, penggunaan lahan berupa tambak dapat dijumpai di setiap kecamatan di kabupaten Rembang. Tambak sebesar $32 \%$ berada di Kecamatan Kaliori, sedangkan kecamatan dengan sedikit tambak sebesar $9 \%$ berada di Kecamatan Kragan. Sebesar $51 \%$ penggunaan lahan berupa tanah terbuka berada di Kecamatan Kragan. Lahan pertanian dapat ditemukan di setiap kecamatan, namun untuk Kecamatan Sluke lahan pertanian banyak ditemukan mengingat Kecamatan Sluke berada di dataran tinggi yang lahannya cocok untuk dimanfaatkan sebagai lahan pertanian.

\section{KESIMPULAN}

Berdasarkan hasil penelitian Kajian Kerentanan Pesisir Pantai Kabupaten Rembang, maka kesimpulan yang dapat ditarik yaitu tingkat kerentanan Kecamatan Kaliori adalah tinggi dengan nilai 375, Kecamatan Rembang adalah sedang dengan nilai 323, Kecamatan Lasem adalah tinggi dengan nilai 358, Kecamatan Sluke adalah sedang dengan nilai 324, Kecamatan Kragan adalah tinggi dengan nilai 380 , dan Kecamatan Sarang adalah tinggi dengan nilai 388. Hal tersebut bila dilihat dari segi kerentanan pantai maka prioritas rehabilitasi pada Kabupaten Rembang, yaitu pada Kecamatan Kaliori, Kragan, dan Sarang.

\section{DAFTAR PUSTAKA}

Bengen, D.G. 2001. Pedoman Teknis Pengenalan dan Pengelolaan Ekosistem Mangrove. Pusat Kajian Sumberdaya Pesisir dan Lautan-Institut Pertanian Bogor. Bogor, Indonesia.

Budiharsono, S. 2001. Teknik Analisis Pembangunan Wilayah Pesisir dan Lautan. Jakarta: Pradnya Pramita.

Danoedoro, P. 1996. Pengolahan Citra Digital. Yogyakarta : Fakultas Geografi. Universitas Gadjah Mada.

Dewanti, R., 1999. Kondisi hutan mangrove diKalimantan Timur, Sumatera, Jawa, Bali, dan Maluku. Majalah LAPAN Edisi Penginderaan Jauh.

Foody, G.M., Campbell, N.A., Trodd, N.M. \& Wood, T.F. 1992. Derivation and applications of probabilistic measures of class membership from the maximum-likelihood classification. Photogrammetric Engineering and Remote Sensing. 58:1335-1341. 
Gornitz, V., Beaty, T. \& Daniels, R. 1997. A Coastal Hazards Data Base for the US West Coast. Goddard Institute for Space Studies. NASA. Publ. No 4590.

Gornitz, V. \& Kanciruk, P. 1991. Assessment of Global Hazards from Sea Level Rise. Proceedings of Sixth Symposium on Coastal and Ocean Managent ASCE Charleston, 11-14 Juli 1991. Hal:1345-1359.

Pribadi, R. 2006. Kajian Konservasi Ekosistem Mangrove Di Desa Pasar Banggi, Kabupaten Rembang. Undip.

Setiyono. 1996. Kamus Oseanografi. Universitas Gajah Mada Yogyakarta. Yogyakarta.

Setyandito, O. 2010. Keseimbangan Profil Pantai Pasir dalam Mendukung Penanggulangan Erosi serta Pendukung Konservasi Lingkungan Daerah Pantai. Laporan Akhir. Lembaga Penelitian dan Pengabdian Kepada Masyarakat, Universitas Gadjah Mada.

Suprapto. 2016. Analisis Kerentanan Fisik Pantai di Pesisir Garut. Universitas Padjajaran Bandung.

Triadmodjo, B. 1999, Teknik Pantai, Beta Offset, Yogyakarta.

Wahyudi, T. \& Hariyanto, S. 2009. Analisa Kerentanan Pantai di Wilayah Pesisir Pantai Utara Jawa Timur. Prossiding. Seminar Nasional Teori dan Aplikasi 2009. Surabaya: Institut Teknologi Surabaya. 